International Journal of Linguistics, Literature and Translation

ISSN: 2617-0299 (Online); ISSN: 2708-0099 (Print)

DOI: $10.32996 / \mathrm{ijlt}$

Journal Homepage: www.al-kindipublisher.com/index.php/ijllt

\title{
Lexical Variations in Pakistani English: A Case Study of the Novel Twilight in Delhi
}

\author{
Maha Sarfraz 8 (D) \\ MPhil Scholar, Department of English, GC Women University, Sialkot, Punjab, Pakistan \\ $\triangle$ Corresponding Author: Maha Sarfraz, E-mail: maha.sarfaraz2@gmail.com
}

ARTICLE INFORMATION ABSTRACT

Received: May 04, 2021

Accepted: June 17, 2021

Volume: 4

Issue: 6

DOI: $10.32996 / i j l l t .2021 .4 .6 .30$

\section{KEYWORDS}

Code-Switching, Language

varieties, Pakistani English,

Postcolonial Literature,

Sociolinguistics factors
The present study investigates the English language variations due to code-switching between L1 (Urdu) and L2 (English). It shows how language varies from culture to culture, religion to religion, and how these variations make language an independent variety. This research also investigates the role of Urdu language in the formation of Pakistani English. It is a corpus-based study. Methodology in the study is both qualitative and quantitative. A mixed approach has been employed. As a sample, a famous postcolonial novel "Twilight in Delhi" by Ahmed Ali has been selected. Analysis shows that the Pakistani native language has an effect on its culture on the English language. This research also investigates various sociolinguistics factors. It shows that the phenomenon of "Borrowing" is frequently used in the novel than compounding and hybridization because of the Islamic religion, historical and societal culture. Edibles are transferred from Urdu into English because they do not have their direct equivalents in English. The results also indicate that the usual use of Urdu words into English at the lexical level is property of Pakistani English and makes it an independent variety.

\section{Introduction}

Pakistani English is a non-native variety of English in Pakistani. It is developed through a language contact situation. There are many reasons for language contact such as trade, social network, conquests, globalizations, missionaries, socialization, immigration etc. (Mahboob, 2015). When a language is exposed to other language, it exerts influence on each other Consequently, a new variety develops. Variety is a neutral term used to refer to any kind of language (Trudgill, 2003). English in Pakistan has its roots back to the time in 1600, when East India's Merchants were sent to the Indian subcontinent to trade with India by Queen Elizabeth. Now Pakistan is separated from British India but both countries (Pakistan and India) use the same patterns of English.

At a macro level, Pakistani English's prestige and the local and international community's attitudes to it are examined. The microlevel concerns linguistic differences, including lexis, syntax, phonology and pragmatics. Kachru (2005) describes Pakistani English as a different variety. He considered it the outer circle country. These outer circle communities/English's are developing varieties. In 1986, he considered Pakistani English an Institutionalized second language variety, which has a long history of cultural and geographical contest (Kachru, 1986). Pakistani English has its features common with Asian and South Asian English because it is its sub variety but still an independent variety. Baumgartner 1987 also considered Pakistani English as an institutionalized variety. It has internal as well as external functions, which makes it an independent variety. English is used in Pakistan differently from when it is used in the native setting because societal and cultural traditions affect English language usage in Pakistan as Baumgardner (1998) says that one has to be familiar with the English language as well as with Urdu language and Islamic culture (Baumgardner, 1998).

Pakistani English writers are now well known by the World and has gained international worth (Hornberger, 1996). Pakistani English literature is receiving national and official awards since 1980s. Pakistani English writers include Alamgir Hashmi who received national honor, Bapsi Sidhwa, Kamila Shamise and Nadeem Aslam. In the early years of 21st century, many Pakistani

\section{K C AL-KINDI CENTER \\ $\mathbf{R}$ D FOR RESEARCH AND DEVELOPMENT}

Your gateway to world-class research

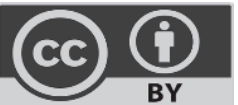

Published by Al-Kindi Center for Research and Development, London, United Kingdom. Copyright (c) the author(s). This open access article is distributed under a Creative Commons Attribution (CC-BY) 4.0 license 
novelist writings in English have been introduced, such as Mohsin Hamid, Uzma Aslam, and Ahmad Ali. These postcolonial writers; have Urdu as their native language. Ahmad is also one of the postcolonial writers who has written the novel "Twilight in Delhi".

\subsection{Significance of Study}

This study of variations in Pakistani English is important because it studies the sociolinguistics factors responsible for bringing about variations in Pakistani English.

\subsection{Objectives of the Research}

The main objectives of the researches are:

- $\quad$ To study the phenomena of lexical variation that occurs in English Pakistani fiction by Pakistani writers.

- To study the reasons behind the variations occurring in Pakistani English.

- To examine how the lexical variations make a non-native variety of English an independent and systematic variety.

\subsection{Research Questions}

The research questions are as follow:

1) What language variety is used by the writer to illustrate specific features of Pakistani English?

2) What are the reasons behind the phenomenon of borrowing occur in Twilight in Delhi?

3) How lexical and semantic variation in Twilight in Delhi makes the non-native variety of English an independent variety?

\subsection{Delimitations}

This research work delimits to study only one aspect of Pakistani English; variations in Pakistani English. This research work is also delimited to an only semantic and lexical variety of English in Twilight in Delhi

\section{Literature review}

\subsection{Indigenization of English}

When the speaker of another language indigenization uses the English Language, the "consequence of interference" occurs. According to him, when foreign elements are introduced in highly structured domains of language, rearrangements of patterns occur that is interference. Highly structured domains of language include the phonemic system, a part of phonology, syntax and some areas of vocabulary (Weinreich, 1953).

\subsection{English as an interference variety}

English in Pakistan and India is the interference variety of English. In different domains, it is used for different purposes and has distinctive features. However, interference only shows linguistic changes in a language contact situation, as Kachru (1986) described. It is linguistically and culturally pluralistic. Kachru (1990) has described the difference in deviation and mistake that is the distinctive feature of non-native varieties of English. The deviation is measured with respect to the norm that is British Standard English in Pakistan and Indiaviation is rule-governed and different from the norm because it is the result of the English linguistic and cultural setting in which the language is used. It develops from a productive process, which makes the specific features. In other words, deviations follow a distinctive pattern, whereas mistakes do not. Thus, when phonological rules of L1 (Urdu) are used to pronounce L2 (English) words, then the deviation that occurs is systematic and rule-governed and makes a different accent. And when cultural context produces new words or changes the meaning of words from L1, lexical and semantic deviations occur (Kachru, 1990). So in the case of Pakistan, interference is produced in the acquisition of the English language by Urdu speakers and a language is produced, have variations that make its own distinctive features, called Pakistani English. Kirkpatrick (2017) points out that, though the investigation of English variants is centuries old, the discipline of World Englishes is relatively new. Kachru, he believes, was a pivotal person in the development of this sociolinguistics sub-discipline.

\subsection{Pakistani English}

PE (Pakistani English) is a non-native variety, which represents its independent linguistic and cultural identity. This individual variety can be determined through language at the lexical, phrasal and sentential level (Azher \& Mehmood, 2016). It is the result of regular contact with the Urdu language. Pakistani English now contains many borrowed words from Urdu and the other regional languages of Pakistan. He also highlighted the area of word formations in Pakistani English (Qurick, 1972). Process of Affixation (Prefix and Suffix) is very important in innovations in Pakistani English (Baumgardner, 1998).

Talaat (2003) has also written about Pakistani English and described it as the changing language; in which changes occur due to its contact with Pakistani languages, specification with the Urdu language. She is of the opinion that the influence of Urdu on PE is evidence of the fact that Pakistani English is an independent variety with divergent lexical structures. 
Pakistani post-colonial writers, which resulted in pidginization, use the English language in Pakistan to indicate the local beliefs of the culture or society. According to Talaat (2002) Pakistani English has passed through the process of pidginization and creolization. She also explains that Urdu and the other regional dialects of Pakistan provide a wide variety of socio-cultural settings of English. Every language is governed by the rules and concepts of its culture. Therefore, it restricts its writers to explain its concept in another language. Such an example can be found in postcolonial literature and point out the limitation of sociolinguistics context of English (Talaat, 2002).

According to Rahman (2020), in Pakistan, the cultural reality is different and Islam and Muslim history develop it. Semantic, morphological, lexical, syntactic, phonological and pragmatic features are prominent in their variety. Rahman divides Pakistani varieties of English into four sub-categories (Rahman, Pakistani English, 2020).

a) Anglicized English: This variety that Pakistanis speak in British settings. They have been exposed to English for a long period.

b) Acrolect variety: This variety is developed by the Pakistani speakers in educational institutions as a medium of instruction. This variety is different from British English in terms of its linguistic features such as semantics, phonology, syntax, lexis and morphology.

c) Mesolect: It is totally different from British English and it is used by Pakistani speakers whose medium of instruction in schools is Urdu.

d) Besilect: It is a kind of Pakistani English pidgin. It is used by speakers who are not much educated.

\subsection{Theoretical Framework}

\subsection{Lexical and Semantic features}

Lexical and semantic features of Pakistani English as discussed by Rahman (2014) used as a framework in this research work. Weinreich (1953) described its features as Borrowing, semantically changed, translated and hybridized.

\subsubsection{Borrowing}

Borrowing occurs in many ways, such as Islamic culture and religion's specific words (registers). In Pakistani English, many words have been borrowed from Arabic, Persian and Sanskrit. When borrowing occurs from these languages, it represents cultural concepts. However, borrowing from Arabic and Persian also occur in the category of Islamic culture. Pakistan has some Islamic, cultural, historical and Indo-Pak concepts which can only be described in their own language. Therefore, borrowing from Urdu in Pakistani English occurs due to these reasons.

\subsubsection{Translations}

In Pakistani English, simple and compound words are directly translated from Urdu. So the creation of neologism occurs. These expressions are either simple or compound words, metaphor or idioms, or full cultural concepts and are directly and literally translated from Urdu into English.

\subsubsection{Hybridization}

Hybridization occurs when compound words are formed, one word is from one language and the other word is from a different language (Trudgill, 2003; Crystal, 2012). Weinreich (1953) differentiate between two types of hybrids. One is as south Asian item as head: one word is transferred and derivative affix is reproduced and the other is modifier: in which one item or stem is native and affix is transferred. Hybridized word in Pakistani English either represents Islam or Pakistani cultural concept.

\subsubsection{Innovations}

By the usage of English prefix and suffixes, many new words are formed in Pakistani English. They are different from loan creations. They are produced by the need of much appropriate concepts to be represented in non-native variety. (Weinreich, 1953)

Apart from the borrowing, innovations, translations, and hybridizations, more devices are used to make works in Pakistani English such as coining and obsolete words, which have been lost in BSE but still in use here.

\section{Research Methodology}

\subsection{Research Design}

The researcher used "mixed approach" for the study. It is qualitative in the sense that a detailed analysis of the novel has been done. On a quantitative level, the data has been presented in the tables and their frequencies in numeral data. As a theoretical framework, a document analysis has been done. Lexical and semantic variations in Pakistani English makes it distinctive from the other varieties of English which have been used worldwide.

\subsection{Tools for Data Collection}


The researcher has used the secondary data collection method in research and the tool of research tool is "Twilight in Delhi" by Ahmed Ali.

\subsection{Sample}

As a sample, the researcher chooses a novel "Twilight in Delhi" by Ahmed Ali from postcolonial literature, which is a true representative of Pakistani English.

\section{Data Collection and Data Analysis}

The data was collected by close reading of the whole novel. The note-taking technique extracted the words from the novel that showed variations in Pakistani English. Variation in Pakistani English is represented in the tables with their explanations. The frequency of the words means at how many times it has been used in the novel is also given in the table. Data is categorized under major categories
a. Borrowing
b. Compounding
c. Hybridizations
d. Greetings
e. Literal translations of some simple phrases
f. Literal translation of metaphor and idiomatic phrases
g. Literal translations of Address term.

\subsection{Borrowing}

Borrowing is a common phenomenon that occurs in the language contact situation. In borrowing, a word is introduced in a language from a foreign language; and that word becomes an integral part of the receipt language. In the case of Pakistani English, Urdu is a donor language and English is a receipt language. Many of the words have been transferred from Urdu to the English language. Pakistani English fiction is the true representative of the variations that occur in language. The novel "Twilight in Delhi" by Ahmed Ali also represented these variations. Borrowed words from the novel are further categorized into:

a. Borrowing from Islamic culture

b. Borrowing from the Indo-Paki culture

c. Borrowing due to the edibles

d. Borrowed verbs.

\section{Table 1: Borrowing from Islamic Culture}

\begin{tabular}{|c|c|c|c|c|}
\hline Sr. no & $\begin{array}{l}\text { Borrowed } \\
\text { (Noun) }\end{array}$ & words & Explanation & Frequency \\
\hline 1. & Saiyyeds & & Direct descendants of Prophet Muhammad & 3 \\
\hline 2. & Azan & & A call for Muslim prayer & 10 \\
\hline 3. & Masjid & & Mosque & 3 \\
\hline 3. & Koran & & Sacred book of Muslims & 6 \\
\hline 4. & Moazzin & & Who calls for prayer in Islam & 5 \\
\hline 5. & Molvi & & A kind of Muslim priest & 5 \\
\hline 6. & Maktab & & Old fashioned oriented house & 2 \\
\hline 7. & Eid & & Islamic religious feast day & 3 \\
\hline 8. & Ramzan & & A month of special prayers of Muslims & 3 \\
\hline 9. & Musalman & & Muslims & 2 \\
\hline 10. & Meelad & & A ritual ceremony of Muslims & 1 \\
\hline
\end{tabular}

Table 2: Borrowing from Indo-Pak Culture

\begin{tabular}{llll}
\hline Sr. no & Borrowed word & Explanation & Frequency \\
\hline 1 & Muhallah & Street & 14
\end{tabular}




\begin{tabular}{|c|c|c|c|}
\hline 2 & Raja & King & 5 \\
\hline 3 & Low Kotha & An upper story & 8 \\
\hline 4 & Lakh & I Lac & 1 \\
\hline 5 & Sherwani & A kind of dress for males & 4 \\
\hline 6 & Bai & Prostitute & 4 \\
\hline 7 & Paan & Leaves of betel plant prepared as stimulant & 7 \\
\hline 8 & Purdah & Curtain & 4 \\
\hline 9 & Hookah & Water pipe & 6 \\
\hline 10 & Attar & Scent & 4 \\
\hline 11 & Zennana & Female lounge & 12 \\
\hline 12 & Sufi & Mystic man & 2 \\
\hline 13 & Attar & Scent & 7 \\
\hline 14 & Qawwals & Form of Sufi devotional music & 7 \\
\hline 15 & Kahars & Vehicle pulled by draft animal & 2 \\
\hline 16 & Nawab & A governor in India during the Mughal empire & 4 \\
\hline 17 & Maidan & Ground & 4 \\
\hline 18 & Doli & A small palanquin & 10 \\
\hline 19 & Domni & Female singer & 4 \\
\hline 20 & Coolie & Labor, who brings luggage & 2 \\
\hline 21 & Hakim & Muslim doctor who uses traditional medications & 2 \\
\hline 22 & Neem & A tree & 3 \\
\hline 23 & Faqir & Beggar & 4 \\
\hline 24 & Kambal & Blanket & 2 \\
\hline 25 & Shah & King & 2 \\
\hline 26 & Haq & True & 4 \\
\hline 27 & Kharkhandar & A proprietor of a petty home industry & 5 \\
\hline 28 & Frangis & English people & 3 \\
\hline 29 & Chammari & Low cast women & 5 \\
\hline 30 & Loafers & Idler & 7 \\
\hline 31 & Chammar & Low caste man & 8 \\
\hline 32 & Mardana & Males' loung & 6 \\
\hline 33 & Saqi & Cup bearers & 2 \\
\hline 34 & Sarangis & Stringed instrument & 4 \\
\hline 35 & Bulbul & Nightingale & 2 \\
\hline 36 & Budha & Old man & 1 \\
\hline 37 & Kababi & One who makes kabab & 4 \\
\hline 38 & Saavan & Rainy weather & 2 \\
\hline 39 & Mureed & Religious disciple & 3 \\
\hline 40 & Sari & An Indian dress for women & 2 \\
\hline 41 & Burqas & A vein & 4 \\
\hline 42 & Loo & Hot wind & 3 \\
\hline 43 & Haray Bharay & Ever green & 3 \\
\hline 44 & Tahmat & Cloth reaching down the ankles, worn mostly by muslims & 4 \\
\hline 45 & Din & Day & 3 \\
\hline 46 & Jinn & Monsters & 3 \\
\hline 47 & Sandals & A kind of cream & 4 \\
\hline 48 & Drabar & Court & 3 \\
\hline 49 & Ghassals & Professional, who washes the dead & 4 \\
\hline 50 & Maqta & Last line of poem & 1 \\
\hline 51 & Dulhan2 & Bride & 2 \\
\hline 52 & Mohurs & Stamps & 3 \\
\hline 53 & Bania p139 & Grocer plus moneylender & 2 \\
\hline 54 & Annas & Lesser than rupees & 2 \\
\hline 55 & Pindis & A special kind of sweet used at marriages ceremony & 2 \\
\hline 56 & Sehra & A kind of garland & 5 \\
\hline 57 & Ubtan & A kind of beauty crème & 7 \\
\hline
\end{tabular}




\begin{tabular}{llll}
\hline 58 & Shohday & Professionals;who congratulates & 3 \\
59 & Vida & Departure & 1 \\
\hline
\end{tabular}

Table 3: Borrowed word: Edibles

\begin{tabular}{llll}
\hline Sr. no & Borrowed words & Explanation & Frequency \\
\hline 1. & Sherbets & Juice & 6 \\
2. & Ghee & Oil & 4 \\
3. & Kababs & Meat cutlass & 4 \\
4. & Pulao & A dish of rice & 1 \\
\hline
\end{tabular}

Table 4: Borrowed Verbs

\begin{tabular}{llll}
\hline Sr. no & Borrowed word & Explanation & Frequency \\
\hline 1. & Painch & A kind of competition in kites flying & 1 \\
2. & Sabbath & A day of rest and prayers & 1 \\
3. & Looted & Robbed & 4 \\
\hline
\end{tabular}

There are a lot of borrowed words in Pakistani English from Urdu. A keen analysis of the given above data shows that words are borrowed from the Islamic culture and religion to fill the lexical gaps in English. There is no concept of Azan, Moazzin, Saiyyeds, Molvi, Maktab, Eid, Ramzan etc. So there is no equal equivalent of these words in English. So these words are borrowed as it is in Pakistani English.

But the analysis of the words borrowed from the Indo-Pak culture represents that culture is also one of the main factors in borrowing the elements. Culture-specific items are transferred from the donor language to the receipt language as it is. Because if there is no equivalent in a foreign language, it does not describe its impact completely. But there are direct equivalent words and a true representative of the words from the Urdu language such as curtain for pardhah, a beggar for faqir, street for mohallah. But despite it, the words have been transferred from Urdu to English. Which concludes that borrowing is used to fill the lexical gaps, but it is also used to represent your own variety of English as an independent variety and it can stand on its own.

\subsection{Compounding}

Compounding is the formation of the words made up of two words, but both words correspond to only one thing. There are also many instances of compounding of Urdu into Pakistani English. Table is representing those:

Table 5: Compounding

\begin{tabular}{llll}
\hline Sr.no & Borrowed word & Explanation & Frequency \\
\hline 1. & Melad-read & A religious ceremony & 2 \\
2. & Carvan.serai & Where someone stays for a while & 1 \\
3. & Mast Qalandar & A mad, mystic person & 4 \\
4. & Pigeon-Flies & One who flies pigeon & 2 \\
5. & Noor Nama & Specific verses in Islam & 1 \\
6. & Eid-gah & Where eid prayers are performed & 2 \\
7. & Angrezi sarkar & English government & 3 \\
8. & Mayun Ceremony & A function before wedding in which brides dyes & 1 \\
9. & her hands with henna & 1 \\
10. & Delivery Panjiriri & A special kind of sweet made only for this & 1 \\
\hline
\end{tabular}

\subsection{Hybridization}

Hybridized words have been used in Pakistani English by the postcolonial writers. Hybridized words are those in which one word is from one language and the other is from the other language. Examples of Hybridization in Pakistani English can be seen as in the novel:

Table 6: 


\begin{tabular}{llll}
\hline Sr. no & Hybridized word & Explanations & Frequency \\
\hline 1. & Bulbul nest & Nightingale nest & 2 \\
2. & Mango Sherbet & Mango juice & 4 \\
3. & Iron Shah & Ironically used in novel for a person & 1 \\
4. & Tonga Driver & A person who droves Tonga & 4 \\
\hline
\end{tabular}

\subsection{Greetings}

Some greetings that are always specific to it Pakistani culture and so to its country are also been used as it is in this novels Such as:

Table 7:

\begin{tabular}{llll}
\hline Sr. no & Borrowed word & Explanations & Frequency \\
\hline 1. & Assalam.u.alaykum & May peace be upon you & 5 \\
2. & Walaikum.u.salam & May peace be upon you also & 5 \\
3. & Allah.u.Akbar & The Muslim battle cry & 2 \\
\hline
\end{tabular}

\subsection{Word-to-word Translation}

There is also a direct translation of some phrases and expressions of Urdu into English that are especially associated with the Pakistani culture and Pakistani language. These phrases are literally translated into the English language, which are given:

Table 8:

\begin{tabular}{llll}
\hline Sr. no & Expression & Urdu expressions & frequency \\
1. & Blood in his eyes & Ankhon mein khoon utarna in urdu & 1 \\
2. & Everything has come to an end sooner or & Her cheez fani hai & 1 \\
& later & Hindustan ka seena & 1 \\
3. & Breast of Hindustan & Nangi Talwar & 1 \\
4. & Naked sword & From Frangiyo & 7 \\
5. & Frangis & From Musalmano & 9 \\
6. & Muslamans & Hathon mein girna & 1 \\
7. & Fell into the hands & & \\
\hline
\end{tabular}

\subsection{Metaphor and Idiomatic phrases}

There is also a direct translation of Urdu idiomatic phrases and metaphors into English. Examples in the novel are given:

Table 9:

\begin{tabular}{llll}
\hline Sr. no & English expressions in novel & Urdu expression & Frequency \\
\hline 1. & Put his foot down & Tang atkana & 1 \\
2. & Cat was out of bag & Billi theley sey bahir aa hi gai & 1 \\
3. & When Husband and wife are willing, what & Jab miyan biwi razi, to kya karey ga Qazi & 1 \\
& can qazi do & & 1 \\
4. & Five finger in ghee these days & Panchon ungliyan ghee mein & 1 \\
\hline
\end{tabular}

Literal translations of some Urdu address terms have also been used in this novel, as the words like Amma used to call mother in Pakistan, Begam used to call someone's wife with his husband name as Begam Nihal in novel, and Bi and Saheb are used just to give respect to someone.

\section{Discussion, Findings and Conclusion}

\subsection{Discussion and Finding}

Among all the categories that have been studied there in creating variations in Pakistani English, Borrowing is the most powerful tool that brings variations in language. In borrowing, culture is the most active phenomena that vary from language to 
language, thus creating variations in Language. The given circle of percentages shows that Borrowing is the most common and most famous feature and source of variations in Pakistani English among all.

\section{Lexical Varieties of Pakistani English}

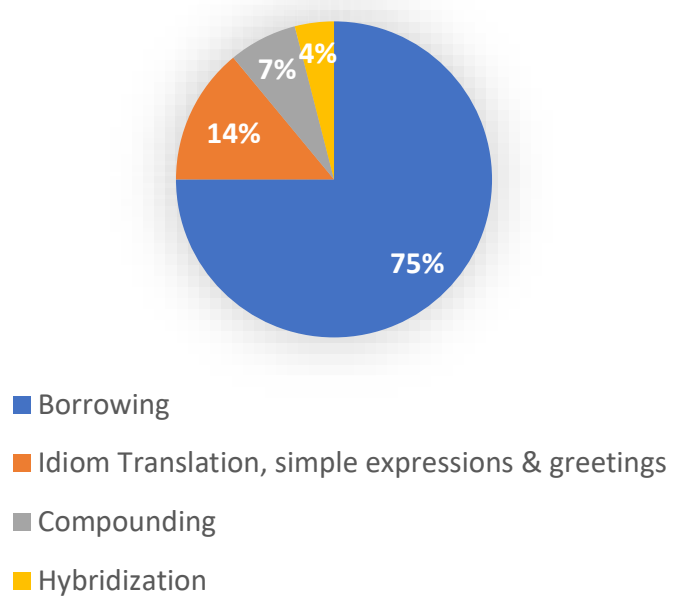

\subsection{Conclusion}

The contact between English and Urdu in the context of Pakistani writings' in English language has been developed along with the postcolonial literature. This paper investigated that Pakistani English writers use many devices that developed variations in the Pakistani English to fill the lexical gaps in English. The above study showed that Borrowing is most commonly used phenomenon and it the most widely used feature of non-native variety that brings about independent variety in language. It also presented that borrowing can occur in any way; through works depicting Islamic culture and religion, or the words that depict the culture of India and Pakistan, and then edible and clothing are also transferred from the Urdu to the English language as kabas, pulao, shalwar kameez, saari etc. But sometimes, it is done to introduce their own language as an independent variety as shown in the novel. Hybridization, compounding, Pakistani culture's greeting and some address terms preserve their form and function in Pakistani English just as to describe the specific concept. So the analysis of all the data showed that Pakistani English has its own distinctive features absent in all other languages. So it is an inseparable and independent variety of English in Pakistan. Current research is limited to only analysis of lexical variations of Pakistani English. Furthermore, the research has great potential for future linguistics scholars, especially those interested in register analysis. It will allow them to semantically and phonologically analyze newsletters, documentaries, and other Pakistani literature for a better and comprehensive understanding of different variations of Pakistani English.

\section{References}

[1] Azher, M., \& Mehmood, M. (2016). Exploring Variation across Pakistani Academic Writing: A Multidimensional Analysis. NUML Journal of Critical Inquiry.

[2] Baumgardner, R. J. (1998). Th English Language in Pakistan. Oxford: Oxford University Press.

[3] Crystal, D. (2012). English as a Global Language. New York: Cambridge University Press.

[4] Hornberger, S. M. (1996). Sociolinguistics and Language Teaching. New York: Cambridge University Press.

[5] Kachru, B. (1986). The Indianization of English: The English Language in India. Delhi: Oxford University Press.

[6] Kachru, B. (1990). World Englishes and Applied Linguistics. World Englishes, 3-20.

[7] Kachru, B. (2005). Asian Englishes: Beyond The Canon. Hong Kong University Press.

[8] Krikpatrick, A. (2017). World Englishes. In Constant Leung \& Brian V Street. In C. Leung, \& V. Street, The Routledge Companion of English Studies (pp. 33-45). New York: Routledge.

[9] Mahboob, A. (2015). In D. Djenar, A. Mahboob , \& K. Cruicks, Language and Identity across Modes of Communication. Berlin: DE GRUYTER MOUTON.

[10] Qurick, R. G. (1972). A Grammar of Contemporary English. London: Longman Publishers.

[11] Rahman, T. (2014). Pakistani English. Islamabad: National Institute of Pakistan Studies.

[12] Rahman, T. (2020). Pakistani English. In B. Kingsley, B. Werner , \& K. Andy , A Handbook of Asian Englishes. Islamabad: Wiley Online Library.

[13] Talaat, M. (2002). Form and Functions of English in Pakistan. Multan: Bahaudin Zakriya University.

[14] Talaat, M. (2003). Pakistani English: A Sociolinguistic Variety. Journal of Research, 4(1), 17-30.

[15] Trudgill, P. (2003). A Glossary of Sociolinguistics. Oxford: Oxford University Press.

[16] Weinreich, U. (1953). Languages in Contact: Feelings and Problems. The Hague: Mouton Publishers. 
